\title{
МОВОЗНАВСТВО
}

\section{СУФІКСИ УКРАЇНСЬКОГО ПОХОДЖЕННЯ В АНТРОПОНІМІКОНІ ПОЛЬСЬКО-УКРАЇНСЬКОГО ПРИКОРДОННЯ}

\author{
МАРТА АБУЗАРОВА \\ Університет імені Адама Міцкевича в Познані, Познань - Польща \\ PRZYROSTKI PROWENIENCJI UKRAIŃSKIEJ \\ W ANTROPONIMII POGRANICZA POLSKO-UKRAIŃSKIEGO \\ MARTA ABUZAROWA \\ Uniwersytet im. Adama Mickiewicza w Poznaniu, Poznań — Polska
}

\begin{abstract}
STRESZCZENIE. Artykuł poświęcony jest analizie formantów nazwiskowych pochodzenia ukraińskiego obecnych $\mathrm{w}$ antroponimii polskiej mieszkańców pogranicza polskoukraińskiego, które z punktu widzenia interferencji językowej wywołuje szczególne zainteresowanie językoznawców. Na tym terenie kultura polska wraz z językiem polskim zetknęła się i uległa wpływom miejscowej ruskiej (ukraińskiej) kultury językowej, co zostało odzwierciedlone w strukturze fonetyczno-morfologicznej badanych antroponimów.
\end{abstract}

\section{SUFFIXES OF UKRAINIAN ORIGIN IN THE ANTHROPONYMY OF POLISH-UKRAINIAN BORDERLANDS}

\author{
MARTA ABUZAROWA \\ Adam Mickiewicz University in Poznan, Poznan — Poland
}

ABSTRACT. The article analyzes surname suffixes of Ukrainian origin, present in Polish anthroponymy of Polish-Ukrainian borderlands. Linguists are particularly interested in Polish-Ukrainian borderlands because here Polish culture along with the Polish language has been affected by the local Ruthenian (Ukrainian) culture and language. Therefore, PolishUkrainian interference is reflected in the phonetic and morphological structure of analyzed anthroponyms.

Ж

одна мова світу не існує без зв'язків, взаємовпливів та зіставлень 3 іншими мовами"1. Результатом цих взаємовпливів мовознавці вважають ,проникнення елементів однієї мови до іншоі”"2. Цей процес передусім актуалізується в прикордонних територіях. Яскравим зразком міжмовних взає-

${ }^{1}$ I. Ф аріон, Українські прізвищеві назви Прикарпатської Львівщчини наприкінці ХVIII - початку ХІХ століття (з етимологічним словником), Львів 2001, с. 9.

${ }^{2}$ В. Ів в нишин, Я. Ра девич-В инницький, Мова і нація. Тези про місие і роль мови в національному відродженні Украӥни, Дрогобич 1994, с. 95. 
мовпливів є українсько-польське прикордоння, що якнайменше з XIV ст. ${ }^{3}$ заселяли, головно, два великі етноси - український та польський. Тривалі контакти обох народів зумовили численні запозичення не лише в апелятивній, а й ономастичній лексиці. Запозичення та впливи в системі ономастичної лексики простежимо на прикладі польського антропонімікону Дрогобича - одного 3 провідних міст польсько-українського прикордоння.

Значні мовні уподібнення, нашарування, запозичення на прикордонних територіях відображені в антропоніміконі регіону такою мірою, що деякі антропонімні одиниці, особливо прізвища, нерідко важко диференціювати за етнічною належністю. Оскільки більшість мовознавців уважає суфікс „головним показником національної приналежності антропоніма"4 (у прізвищах морфологічного способу творення ${ }^{5}$, то важливим елементом у процесі міжмовних антропонімних запозичень уважаємо не тільки фонетичні й лексичні запозичення, що, безумовно, домінують, але й морфемні, найчастіше суфіксальні. Саме тому проаналізуємо українські суфіксальні запозичення ${ }^{6}$, що збереглися в польському антропоніміконі польсько-українського прикордоння в прізвищах мешканців Дрогобича к. XVIII - поч. XIX ст.

Ця наукова розвідка — узагальнення аналізу 7754 прізвищ (після відбору однакових антропонімних одиниць їх залишилось 2400), розшифрованих із шести римо-католицьких метричних книг Дрогобича ${ }^{7}$, iз записами, здійсненими протягом $1784-1816$ рр. ${ }^{8}$. Ці книги зберігаються у фондах Центрального Державного Історичного Архіву України у Львові та Головного Архіву Давніх Актів у Варшаві. Вибрані прізвища належать парафіянам римо-католицького храму (латинський обряд), що на той час здебільшого свідчило про польську національну належність, адже до к. XIX - поч. XX ст. в межах досліджуваного регіону національну належність ототожнювали з віровизнанням.

${ }^{3}$ А. Кондрацьки й, Поляки на Україні в $X-X I X \mathrm{~cm}$., [в:] „Український історичний журнал”, № 12 (369), грудень 1991, Київ, с. 84.

${ }^{4}$ В. Гор пинич, А. Корнієнко, Антропонімія Дніпровського Припоріжжя і суміжних регіонів Украӥни, [в:] Ономастика і апелятиви, вип. 25, за ред. В. Гор п ин ича, Дніпропетровськ-Миколаїв 2006.

${ }_{5}^{5}$ Примітка. 3 огляду на морфологію українські й польські прізвища зазвичай ототожнюють з іменниками або прикметниками, тому переважно у прізвищах є суфікси.

${ }^{6}$ Примітка. Запозичення - це звук, морфема, слово і т. д., перенесені з однісї мови в іншу, або сам процес перенесення.

${ }^{7}$ Примітка. Метричні книги: 1) Liber Natorum Civitatis Drohobycz ab anno 1784 - 1791, t. II / Метрична книга із записами про хрещення парафіян протягом 1784 - 1791 рр., м. Дрогобич, т. II (mikrofilm nr A-84275, nr sygn. 3, zespół nr 437, AGAD); 2) Liber Natorum Civitatis Drohobycz ab anno 1792 - 1812, $t$. III, IV, $V$ / Метрична книга із записами про хрещення парафіян проотягом 1792 - 1812 рр., м. Дрогобич, т. III, IV, V (mikrofilm nr A-84275, nr sygn. 3, zespół $\mathrm{nr} 437, \mathrm{AGAD})$; 3) Книга із записами про одруження парафіян протягом 1792 - 1829 рр., м. Дрогобич (спр. 1720, опис 4а, фонд 201, ЦДІАЛ УКРАЇНИ); 4) Liber Copulatorum Civitatis Drohobycz, $a b$ anno 1784 - 1792, t. II / Книга із записами про одруження парафіян протягом 1784 - 1792 pp., м. Дрогобич, т. II (mikrofilm nr A-84275, nr sygn. 3, zespół nr 437, AGAD); 5) Liber Mortuorum pro Civitate Drohobycz ab anno 1792 ad annum 1800, t. III / Метрична книга із записами про смерть парафіян протягом 1792 - 1800 pр., м. Дрогобич, т. ІІІ (спр. 1719, опис 4а, фонд 201, ЦДІАЛ УКРАÏHИ); 6) Liber Mortuorum Civitatis Drohobycz ab anno 1784 - 1791, t. II / Метрична книга із записами про смерть парафіян протягом 1784 - 1791 pр., м. Дрогобич, т. II (mikrofilm nr A-84275, nr sygn. 3, zespół nr 437, AGAD).

${ }^{8}$ Примітка. Період к. XVIII - поч. XIX ст. обрано невипадково: саме 31784 р. збереглася копія найстарішої метричної книги римо-католицької парафії Дрогобича. До 1816 р. записи в метричних книгах вели систематично, проте далі впорядкованість дещо порушилася, тому ця дата обрана як кінцева. Крім того, саме зазначений проміжок часу вважають періодом стабілізації прізвищ у сучасному розумінні цієї антропонімної категорії. 
Уважаємо за доцільне звернути увагу на проблему визначення способу творення прізвищ, а відтак, і виявлення антропонімного форманта (суфікса). 3'ясовано, що мають місце значні розходження „в оцінці словотвірної структури деяких категорій власних назв різними дослідниками та ономастичними школами": про це проблемне питання писав Д. Бучко9.

На прикладі прізвищ на -k(o), -uszk(o) (як-от: Feduszko, Hawryszko ${ }^{10}$ ) спробуємо описати два можливі підходи до визначення способу їхнього творення. Перший грунтується на розгляді прізвищ на кшталт Feduszko, Hawryszko як ceмантичних патронімів (йдеться про перенесення з батька на сина зменшенопестливої форми імені): „Серед суфіксальних варіантів слов'янських відкомпозитних та християнських імен деривати на -ко дослідники ставлять на перше місце. Суфікс -ко приєднувався до повних і скорочених основ та до низки суфіксальних варіантів імен, тому численні прізвища типу Данилко, Іванко, Демко, Грицько можна кваліфікувати як семантичні деривати"11. Згідно з іншим підходом ці прізвища утворені внаслідок приєднання прізвищевих формантів до кореня: „Якщо у давній антропонімії суфікс -ко відзначався переважно як нейтральний формант особових імен, то у пам'ятках пізнішого періоду дослідники кваліфікують його як патронімний суфікс. На таку його функцію вказують і записи в історичних документах з Бойківщини: Ficko — він же Ficak. Tому згадані вище прізвища і численні аналогічні до них могли утворитися морфологічним способом від антропонімів Іван, Гриць і т. д.”'2. Очевидно, не слід відкидати жодної з версій творення таких прізвищ, проте в процесі аналізу надаємо перевагу морфологічному способу творення прізвищ на зразок Feduszko, Hawryszko. Подібну позицію щодо способу творення патронімічних прізвищ із суфіксом -k(o) відстоюють Б. Крея ${ }^{13}$, О. Баранівська ${ }^{14}$, Л. Гумецька, яка, зокрема, наголошує, що „демінутивно-експресивний суфікс -к-, який часто поєднувався з іншими суфіксальними морфемами, уже в староукраїнську добу втратив первинне демінутивне значення, а також похідне експресивне і перетворився на нейтральний структурний формант особових назв, що особливо помітно на прикладі двоосновних слов'янських особових назв і церковних імен" 15 .

Серед прізвищ дрогобичан, зафіксованих у римо-католицьких метричних книгах, виділяємо дві групи одиниць з українськими суфіксами:

1. Українські прізвища. До власне українських прізвищ зараховуємо ті, що утворені на базі української твірної антропонімооснови та українського форманта. Українські прізвища потрапили в римо-католицькі метричні книги, не зазнаючи полонізації, тому з огляду на українські суфіксальні запозичення в польських прізвищах ця група не викликає особливого зацікавлення: іiї розглядатимемо оглядово. Найпоширенішими формантами українських прізвищ дрогобичан уважаємо такі суфікси:

a) -k(o) (іноді ускладнені додатковими суфіксами -ysz, -usz), який уважають характерним суфіксом українських прізвищ ${ }^{16}$ : Demko, Feduszko, Hawrysz-

\footnotetext{
${ }^{9}$ Г. Буч ко, Д. Буч ко, Історична та сучасна українська ономастика, Чернівці 2013, с. 15.

${ }^{10}$ Примітка. Прізвища, розшифровані із перелічених вище метричних книг, виділені курсивом.

${ }^{11}$ Там само, с. 51-52.

${ }^{12}$ Там само.

${ }^{13}$ B. Kreja, Stowotwórstwo polskich nazwisk, Kraków 2001, s. 236.

${ }^{14} \mathrm{O}$. Баран ів ська, Прізвищеві гібриди з формантами -к(о), -енк(о), [в:] Актуальні питання антропоніміки, Зб. матер. наук. читань пам'яті Ю. К. Редька, Київ 2005, с. 31-32.

15 Л. Гумецька, Нарис словотворчої системи української актової мови XIV - XV cm.,

${ }^{16}$ Ю. Редько, Сучасні украӥнські прізвища, Київ 1966, с. 13.
} Київ 1958, с. 13. 
ko, Jamroszko, Kuczko, Pańko (Panko). Українські прізвища 3 формантом -k(o) здебільшого творилися від чоловічих християнських імен (іххніх українізованих форм або тих імен, що функціонували, головно, серед християн східного обряду — православних та греко-католиків): Дем'ян (порівн. пол. Damian), Феdip (порівн. пол. Teodor), Гаврило (порівн. пол. Gabriel) і под. Сумнів викликає прізвище Bojaczko, утворене від пол. апелятива bój або укр. боятися, через що це прізвище зараховуємо до системи власне українських;

б) -uk, -czuk, що слугують для деривації українських прізвищ ${ }^{17}:$ Antończuk (укр. ім. лат. походження Антон(iŭ) + укр. суфікс -czuk), Krawczuk (твірна основа Крав-, що однаково функціонує в польській та українській мовах, + -czuk). Привертає увагу походження прізвища Pynczuk, у структурі якого відсутній прізвищевий формант, оскільки воно утворене семантичним способом від укр. етноніма пінчук - 'житель Пінщини'. Основа етноніма мотивована назвою міста Пінськ, що розташоване на території Білорусі, зі східнослов'янською диспалаталізацією початкового приголосного [п]. Давнішу назву міста Пінськ українці записували як Пинськ, тому й прізвище в основі зберегло [и] замість сучасного [i]. Це явище нотує український словник Б. Грінченка ${ }^{18}$. Фіксуємо ще одне прізвище з українським суфіксом - Rewerenczuk (Reverenczuk), мотиваційна основа якого походить, найімовірніше, від діал. апелятива реверенда (слово лат. походження (від reverenda, reverendus) — „високоповажний”, що вживалося як розмовне на позначення "підрясника"19);

в) -yszyn/-iszyn: Hryczyszyn, Juryszyn, Myszczyszyn (Myscyszyn, Misciszyna) один із небагатьох матронімічних суфіксів, що служить для творення прізвищ від жіночих назв із суфіксом -ych(a) ${ }^{20}$ : напр., укр. прізвисько Грицишин означало „син Грицихи”, Юришин — „син Юрихи” і т. д.;

г) твірний суфікс -уn у прізвищах Weredyn (Werydyn) і полонізованому Weredynowa, що утворені від укр. розм. вереда, вередун ${ }^{21}$;

д) суфікс -uch у прізвищах українського або білоруського походження Trybuch (Tribuch) і похідних Trybuchowa, Trybuchowna (Trybuchuwna), що утворені на базі білоруського апелятива трыбух — „шлунок”, який у розмовному мовленні вживають у значенні „живіт” (на території всієї Білорусі) $)^{22}$. Суфікс -исһ також фіксуємо в укр. апелятиві скрипух $\leftarrow$ скрипіти. Він став мотиваційною основою прізвища Skrypuch і похідних полонізованих Skrypuchiewicz, Skrypuchowna;

е) прізвища на -ci(o)/-ci(a) (прізвище Iwancio: укр. Іван + -сі(о)), крім українського, існують також і в польському антропоніміконі, проте вони „розповсюджені на південно-східних теренах Польщі, мають регіональний характер. У літературній мові їм відповідають загальнопоширені форми 3 -k: Stefcia — Stefka, Romek - Romcio"23. Регіональний суфікс -ci(o) міг поширюватися на південно-східних польських теренах під впливом української мови, що дає змогу припускати його український родовід.

${ }^{17}$ Ю. Ре дько, Довідник українських прізвищ, Київ 1968, с. 42.

${ }^{18}$ Словарь української мови, упор. 3 дод. влас. матеріалу Б. Грінченко, в 4-х томах, Київ 1958 , т. 3 , с. 152.

${ }^{19}$ Н. Пуряєв а, Словник иерковно-обрядової термінології, Львів 2001, с. 96.

${ }^{20}$ Ю. Ре дько, Довідник украӥнських..., с. 41.

${ }^{21}$ Етимологічний словник украӥнської мови, у 7 томах, редкол. О. С. Мельничук, (гол. ред.) та ін., Київ 1982, т. 1, с. 352-353.

22 Лексічны атлас беларускіх народных гаворак, в пяці тамах, пад рэд. Ю. Мацкевіч, Чалавек, Мінск 1996, т. 3, карта № 89.

${ }^{23}$ J. D o min, Stowotwórstwo hipokorystyków od imion własnych od imion własnych osobowych w języku polskim i rosyjskim, Gdańsk 1982, s. 55. 
2. Прізвища-гібриди (полонізовані українські прізвища або польські прізвища $з$ українськими суфіксальними впливами та запозиченнями). Ці прізвища зараховуємо до групи польських, оскільки вони утворені на базі польської / полонізованої твірної основи або пройшли адаптацію до чинних норм польської мови за допомогою актуалізації відповідних фонетичних чи морфологічних засобів. Серед досліджуваних прізвищ виокремлюємо антропонімні структури 3, імовірно, польськими антропонімоосновами та типовим українським формантом -k(o): Kapko (від пол. kapać або пол. kapa), Mrozko (від пол. mróz, mrozić), Objurko (етимон визначити важко; можливо, від пол. obierać або oburzyć się). Як було зазначено, на "українськість" суфікса -k(o) вказує багато мовознавців, порівн.: „У власних назвах (селянських, міщанських, шляхетських) суфікси -ko та -о були зосереджені на території Східних кресів [теперішні території Західної України, Білорусі та Литви, що колись належали Польщі - прим. автора - M. A.] Речі Посполитої, а також на Підляшші, східних теренах Малопольщі й Мазовії. На тих теренах навіть відбувалася заміна прізвищевих суфіксів -ек на -ko, наприклад Łokotko, Lestko, Kruczko, Wieczorko"24.

Сумнівним уважаємо походження прізвищ Pareko і Pinko, мотиваційні основи яких визначити однозначно не вдалося.

Виразним українським антропонімним формантом $\epsilon$ суфікс -uk, за допомогою якого утворені прізвища із власне польськими антропонімоосновами Pawetszczukowa, Pawetszczukowna $\leftarrow$ Pawełszczuk (від пол. імені Paweł; порівн. укр. Павло).

Формантом, що характерний для антропонімів українського мовного простору, є суфікс -enk(o) - чи не найпродуктивніший формант українських прізвищ ${ }^{25}$. Ю. Редько вважає прізвища із суфіксом -enk(o) найтиповішими українськими прізвищами: „Якщо вони й зустрічаються серед інших слов'янських народів, то переважно як прізвища українського походження". За допомогою цього суфікса зазвичай творилися прізвиська від імені батька або (рідше) матері, що пізніше переходили в категорію прізвищ. На матеріалі польських католицьких метричних книг Дрогобича кілька разів фіксуємо прізвище-українізм із суфіксом -enk(o): Chromenko (від старопол. ап. chromy (тепер kulawy) — „кульгавий” або від староукр. ап. хромати - „кульгавити”, хромота — „кульгавість”26) i його варіант із суфіксом -eńk(o) - Chromeńko, а також похідне жіноче прізвище Chromenkowna. На прикладі жіночого прізвища Chromenkowna простежуємо адаптацію українського антропоніма на польському мовному грунті шляхом додавання польського суфікса із значенням належності (у цьому разі, найімовірніше, належності доньки батькові) -own(a) до прізвища з власне українським формантом -enk(o) - Chrom+enko+owna.

Суфікс -ych(a)/-ich(a) - ще одне типове морфемне запозиченням зі східнослов'янських мов: формант використовували для творення „тільки східнослов'янських назв жіночого роду або за родом діяльності чоловіка або на означення жінок за їх власною професією”27. Цей суфікс характерний для укра-

${ }^{24} \mathrm{~J}$. Kość, Polszczyzna poludniowokresowa na polsko-ukraińskim pograniczu językowym $w$ perspektywie historycznej, Lublin 1999, s. 47-48.

${ }_{25}$ В. Гор п ин ич, Сучасна украӥнська літературна мова. Морфеміка, словотвір, морфонологія, Київ 1999, с. 40.

${ }^{26}$ Словник староукраӥнської мови XIV - XV cm., у 2 томах, редкол.: Д. Гринчишин, Л. Гумецька (гол.), I. Керницький та ін., Київ 1978, т. 2, с. 520.

${ }^{27}$ І. Ков а л и к, Особливості іменникового словотвору східнослов'янської мовної групи, [в:] Питання слов'янського мовознавства, т. 9, 1963, с. 8. 
їнських жіночих прізвищ і в польській антропонімії з'явився під впливами української та білоруської мов ${ }^{28}$. У наших джерелах фіксуємо два андроніми Motyczycha i Dudzicha, - утворені за допомогою суфіксів -усh(а) / -ich(a). Варіанти суфіксів формально вважають одним суфіксом, проте форма -уch(a) здебільшого поширена на українських теренах, варіант -ich(a) зафіксовано в російській і (дещо рідше) в білоруській мовах. Щодо прізвища Motyczycha, то не можемо однозначно стверджувати про факт запозичення, адже прізвище могло потрапити до списку поляків разом зі своїм носієм-українцем (в українській мові, як і в польській, поширене чоловіче прізвище Moтика / Motyka, від якого й утворена жіноча форма). У прізвищі Dudzicha до власне польської твірної основи dudz- (східнослов' янська основа мала б вигляд $\partial y \partial-/ d u d-$ ) додано східнослов' янський суфікс -ich(a).

Цікавим з огляду походження є суфікс -ajlo в таких прізвищах дрогобичан, як Szepayło i Szczepajłowa. Він став дериваційним елементом апелятивів і антропонімів і в польській (напр., пейоративно конотовані апелятиви szukajło, jąkajło; антропоніми Drygajło, Dekajło), і в українській мовах (для прикладу, апелятиви міняйло, балакайло; антропоніми Мацайло, Мазайло). Є декілька версій щодо походження суфікса -ajło, які описує польський лінгвіст С. Гала' ${ }^{29}$. Мовознавець виокремлює чотири теорії походження суфікса: а) з польсько-литовського, білоруського і литовського прикордоння; б) українську або руську; в) польську. Прибічником українського походження форманта -ајłо став, напр., С. Грабець, який убачає в українських апелятивах із суфіксом -ајłо лексеми, запозичені польською художньою літературою в др. пол. XVI ст. Відсутність білоруського акання, на думку С. Грабця, також доводить українське походження суфікса. "Українськість" форманта -ајłо підтримують С. Роспонд та М. Шимчак, a А. Брюкнер переконаний, що цей пейоративний суфікс походить виключно “з руських мов" 30 . Очевидно, більшість антропонімів 3 -аjlo територіально розповсюджені в східній і південно-східній частинах Польщі ${ }^{31}$. Мовознавці доводять українську версію походження антропонімного суфікса -ајłо.

Ще одним українським морфемним запозиченням польської мови вважають формант -ес́. Г. Улашин доводить, що використання форманта -ес (-ець) для деривації етнонімів - це риса, характерна виключно східнослов'янським мовам $^{32}$. Прізвище Ukrainiecowa фіксуємо в римо-католицьких метричних книгах: за допомогою суфікса -ес утворений етнонім українець $\rightarrow$ прізвище Українец̧ь / Ukrainiec $\rightarrow$ Ukrainiecowa (це факт семантичного запозичення).

Більшість польських мовознавців (напр. Я. Рігер) звертають увагу на один iз давніх східних впливів на польські прізвища - пристосування польського суфікса -іс до литовсько-руського -ісz ${ }^{33}$. Така адаптація відбувалася ще в XVII ст. У метричних книгах Дрогобича к. XVIII - поч. XIX ст. майже не знаходимо залишків суфікса -іс. Сдиним прикладом, що репрезентує цей суфікс, є жіноче прізвище Wienckowicowna, утворене від чоловічого Wienckowic. Важко зрозуміти, чи прізвище зберегло старопольський антропонімний суфікс -ic, чи церков-

28 J. Kość, Polszczyzna południowokresowa na polsko-ukraińskim pograniczu językowym w perspektywie historycznej, Lublin 1999, s. 48.

29 S. Gala, Apelatywno-antroponimiczne struktury z sufiksem -ajło, [w:] Acta Universitatis Lodziensis, Folia Linguistica 27, Łódź 1993, s. 77-85.

${ }^{30}$ Ibidem, s. 77-87.

${ }^{31}$ Ibidem, s. 82-83.

${ }^{32}$ H. Uła s zyn, Pochodzenie etniczne nazwy Ukrainiec, Łódź 1947.

${ }^{33}$ A. Brückner, Poczatki i rozwój języka polskiego, Warszawa 1974, s. 408. 
ник, який робив відповідні записи, помилився. Оригінальний прізвищевий формант -icz настільки вкоренився в польському антропоніміконі, що сьогодні без глибших генеалогічних досліджень лише на підставі присутності форманта -icz неможливо відмежувати антропонімні одиниці.

Отже, у цій науковій розвідці підтверджено висновки мовознавців, які досліджували польсько-українське прикордоння щодо активності суфіксальної деривації: на українсько-польському прикордонні в галузі суфіксальної деривації зафіксовані „обопільні впливи однієї мови на іншу”, а „вплив українського субстрату засвідчений не тільки серед загальних назв, а й серед антропонімів" ${ }^{4}$. Незважаючи на те, що українські суфікси репрезентовані в антропоніміконі дрогобичан, закцентуємо увагу на наявності низького показника українських формантів саме в польських прізвищах, адже більшість прізвищ, що містять українські твірні суфікси, утворені на базі українських антропонімооснов, тому їх не розглядаємо як польські чи полонізовані, а зараховуємо до системи власне українських прізвищ (Antończuk, Feduszko, Juryszyn та ін.).

Проведений аналіз польського антропонімікону мешканців Дрогобича ${ }^{35}$ дає право стверджувати, що польських / полонізованих прізвищ з твірними основами українського походження значно більше (бл. 15 \%), ніж прізвищ, що містять українські суфікси (бл. 2 \%). Цей факт, очевидно, свідчить про масову полонізацію українських прізвищ протягом XVII - XVIII ст. на польсько-українському прикордонні шляхом додавання польських суфіксів або заміною українських формантів польськими.

${ }^{34}$ Г. А А кушин, Польсько-українське порубіжжя у світлі суфіксальної дериваиії, [w:] Jezzyk i kultura na pograniczu polsko-ukraińsko-białoruskim, pod red. F. Czyżewskiego, Lublin 2001, s. 111.

35 Примітка. Кандидатська дисертація М. Абузарової Polskie nazwiska mieszkańców Drohobycza końca XVIII i początku XIX wieku na tle wschodniostowiańskim знаходиться в базі AMUR (Repozytorium Uniwersytetu im. Adama Mickiewicza). 